\title{
Localization and characterization of Xylella fastidiosa haemagglutinin adhesins
}

\section{Correspondence \\ Bruce C. Kirkpatrick \\ bckirkpatrick@ucdavis.edu}

Received 22 December 2009

Revised 30 March 2010

Accepted 2 April 2010

\author{
Tanja M. Voegel, ${ }^{1}, 2$ Jeremy G. Warren, ${ }^{2}$ Ayumi Matsumoto, ${ }^{3}$ \\ Michele M. Igo $^{3}$ and Bruce C. Kirkpatrick ${ }^{2}$ \\ ${ }^{1}$ Center for Applied Biosciences, University of Freiburg, Germany \\ ${ }^{2}$ Department of Plant Pathology, University of California, Davis, CA 951616, USA \\ ${ }^{3}$ Department of Microbiology, University of California, Davis, CA 951616, USA
}

Xylella fastidiosa is a Gram-negative, xylem-inhabiting, plant-pathogenic bacterium responsible for several important diseases including Pierce's disease (PD) of grapevines. The bacteria form biofilms in grapevine xylem that contribute to the occlusion of the xylem vessels. $X$. fastidiosa haemagglutinin (HA) proteins are large afimbrial adhesins that have been shown to be crucial for biofilm formation. Little is known about the mechanism of $X$. fastidiosa HA-mediated cell-cell aggregation or the localization of the adhesins on the cell. We generated anti-HA antibodies and show that $X$. fastidiosa HAs are present in the outer membrane and secreted both as soluble proteins and in membrane vesicles. Furthermore, the HA pre-proteins are processed from the predicted molecular mass of $360 \mathrm{kDa}$ to a mature $220 \mathrm{kDa}$ protein. Based on this information, we are evaluating a novel form of potential resistance against PD by generating HA-expressing transgenic grapevines.

\section{INTRODUCTION}

Xylella fastidiosa, a Gram-negative, xylem-inhabiting bacterium, causes economically important plant diseases including Pierce's disease (PD) of Vitis vinifera grapevines (Hopkins, 1989) and citrus variegated chlorosis in citrus trees (Rossetti et al., 1990). X. fastidiosa is transmitted by numerous xylem-feeding insects such as sharpshooters and spittlebugs (Hewitt et al., 1946). Once introduced by their vectors, the bacteria multiply in the xylem of infected plants and form microcolonies and three-dimensional biofilms that cause blockage of the xylem vessels. These blockages are thought to be the major cause of the development of symptoms that are similar, but not identical, to water stress and eventually result in the death of the grapevines (Hopkins, 1989; Thorne et al., 2006). X. fastidiosa was the first plant-pathogenic bacterium to have its genome sequenced (Simpson et al., 2000; Van Sluys et al., 2003). The comparatively small genome (2.5 Mb) may explain $X$. fastidiosa's limited niches, occupying only the insect foregut and the plant xylem. In both locations, the bacteria are exposed to high turbulence, an environment low in nutrients, and host defence responses (O'Toole et al., 1999). These conditions make the formation of a bacterial biofilm a key element in X. fastidiosa survival and replication (de Souza et al., 2003; Guilhabert \& Kirkpatrick,

Abbreviations: $A D$, adhesion domain; $H A$, haemagglutinin; $F H A$, filamentous haemagglutinin; PD, Pierce's disease; TPS, two-partner secretion pathway.
2005; Rodrigues et al., 2008). Biofilm formation in X. fastidiosa is thought to be a sequential process in which planktonic cells attach to host surfaces, self-aggregate with other cells and form a biofilm matrix which consists of exopolysaccharides, proteins and probably DNA (Guilhabert \& Kirkpatrick, 2005; Lin, 2009; Roper et al., 2007). The first step in biofilm formation, attachment to host surfaces, is mediated by several different factors, including fimbrial and afimbrial adhesins on the bacterial surface (Li et al., 2007). Fimbrial adhesins can be divided into two classes: long $(1-5.8 \mu \mathrm{m})$ type IV pili encoded by pil genes, and short $(0.4-1.0 \mu \mathrm{m})$ type I pili encoded by the fim operon (Meng et al., 2005). Long pili are positioned at the poles and are responsible for $X$. fastidiosa's twitching motility (Meng et al., 2005), whereas short pili play a role in biofilm formation (Feil et al., 2007).

The best-studied afimbrial adhesins are produced by animal bacterial pathogens such as the filamentous haemagglutinin (FHA) of Bordetella pertussis, the causal agent of whooping cough in humans (Locht, 2007). This major secreted and cell-associated adhesin is responsible for attachment of the bacterium to several host cell types in vitro (Locht, 2007) and for the formation of bacterial aggregates by homotypic interactions (Menozzi et al., 1994a). FHA possesses three different binding sites: a carbohydrate-binding site (Liu et al., 1997), a heparinbinding site (Menozzi et al., 1994b) and an RGD (Arg-GlyAsp) cell-attachment motif possibly involved in host cell integrin binding (Relman et al., 1990). The large $367 \mathrm{kDa}$ 
precursor protein is secreted via a two-partner secretion pathway (TPS) (Guedin et al., 2000; Jacob-Dubuisson et al., 2001, 2004). A recent study, in which the crystal structure of the FHA-secreting protein FhaC was determined, proposed that the N-terminal TPS secretion domain of FHA interacts with protein domains on FhaC, leading to translocation across the outer membrane (Clantin et al., 2007; Kim et al., 2007). The C-terminal third of the FHA protein is proposed to act as a secretion chaperone (Renauld-Mongenie et al., 1996). Once present on the bacterial surface, FHA is processed to a mature 220 $\mathrm{kDa}$ protein by SphB1, a specific protease of the subtilisin family (Coutte et al., 2001). To date, afimbrial adhesins have been poorly characterized in plant-pathogenic bacteria, although the increasing number of genome sequencing projects show a wide occurrence of these adhesins in plant pathogens (Gottig et al., 2009; Rojas et al., 2002). In Erwinia chrysanthemi EC16, the adhesin HecA contributes to the attachment, aggregation, epidermal cell killing and virulence phenotypes of the bacteria on Nicotiana clevelandii seedlings (Rojas et al., 2002). The $X$. fastidiosa genome codes for two haemagglutinins (HAs), HxfA (PD2118) and HxfB (PD1792), which represent the largest genes in the $X$. fastidiosa genome (10374 and 10134 bp, respectively; Simpson et al., 2000; Van Sluys et al., 2003). The importance of these adhesins in $X$. fastidiosa biology has been demonstrated in both pathogen-plant (Guilhabert \& Kirkpatrick, 2005) and pathogenvector (Killiny \& Almeida, 2009) interactions. Knockout mutations of either HA gene, $h x f A$ or $h x f B$, result in hypervirulent strains when inoculated into grapevine stems and in a loss of microcolony and biofilm formation in vitro and in planta (Guilhabert \& Kirkpatrick, 2005). Furthermore, the mutant strains bind less effectively to polysaccharides that are found in the foregut of the insect vector and are therefore less transmissible (Killiny \& Almeida, 2009).

The purpose of this study was to identify the location of $X$. fastidiosa HAs on the bacterial cell and better understand the processing of the HA precursor protein. As described for other pathogens, we found that $X$. fastidiosa HAs are secreted as soluble proteins into the medium and are present in the outer membrane. We also show that $X$. fastidiosa produces vesicles that contain HA proteins. These vesicles might be responsible for delivering virulence factors to distal locations and could account for the appearance of symptoms in leaves not colonized by $X$. fastidiosa.

\section{METHODS}

Bacterial strains and growth conditions. $X$. fastidiosa Temecula wild-type strain and the mutant strains HxfA and HxfB (Table 1) were grown on solid PD3 medium (Davis et al., 1981) without and with kanamycin $\left(5 \mu \mathrm{g} \mathrm{ml} \mathrm{m}^{-1}\right)$ at $28{ }^{\circ} \mathrm{C}$ for 10 days. Liquid cultures were grown by inoculating a $10^{8}$ c.f.u. $\mathrm{ml}^{-1}$ bacterial suspension in a 1:100 dilution into liquid PD3 without and with kanamycin $\left(5 \mu \mathrm{g} \mathrm{ml}^{-1}\right)$. Cultures were grown for 10 days at $28^{\circ} \mathrm{C}$ with agitation at 100 r.p.m.

Cloning, expression and generation of anti-HA antibodies. PD1792 (HxfB) was amplified using the Expand Long Template PCR

Table 1. Strains, plasmids and primers

\begin{tabular}{|c|c|c|}
\hline Strain, plasmid or primer & Characteristics and sequences $^{*}$ & Source \\
\hline \multicolumn{3}{|l|}{ Strains } \\
\hline E. coli TOP10 & $\begin{array}{l}\mathrm{F}^{-} \text {mcrA } \Delta(\text { mrr-hsdRMS-mcrBC) } \phi 80 \text { lacZ } \Delta \mathrm{M} 15 \Delta \text { lacX74 recA1 araD139 } \\
\Delta(\text { ara-leu }) 7697 \text { galU galK rpsL }\left(\mathrm{Str}^{\mathrm{R}}\right) \text { endA1 nupG }\end{array}$ & Invitrogen \\
\hline E. coli ArcticExpress (DE3) & $\mathrm{F}^{-}$ompT hsdS $\left(\mathrm{r}_{\mathrm{B}}^{-} \mathrm{m}_{\mathrm{B}}^{-}\right) d c m^{+} \operatorname{Tet}^{\mathrm{r}}$ gal $\lambda(\mathrm{DE} 3)$ endA Hte $\left(\right.$ cpn10 cpn60 Gent $\left.{ }^{\mathrm{R}}\right)$ & Stratagene \\
\hline X. fastidiosa Temecula & Wild-type & Guilhabert et al. (2001) \\
\hline HxfA & X. fastidiosa Temecula PD2118:: (EZ:: TN $<$ Kan-2>Tnp $)$ & Guilhabert \& Kirkpatrick (2005) \\
\hline \multicolumn{3}{|l|}{ Plasmids } \\
\hline pCR-XL-TOPO & $\operatorname{Kan}^{\mathrm{R}} \mathrm{Amp}^{\mathrm{R}}$, lac $Z, \mathrm{~T} 7$ & Invitrogen \\
\hline pCR-PD1792 & pCR-XL-TOPO vector with gene PD1792 & This study \\
\hline $\mathrm{pET} 30 \mathrm{~b}(+)$ & $\mathrm{Kan}^{\mathrm{R}}$, T7 lac & Novagen \\
\hline pET-AD1-3 & pET30b $(+)$ vector with AD1-3 insert & This study \\
\hline pET-AD4 & pET30b $(+)$ vector with AD4 insert & This study \\
\hline AD1for & GTCTCATGACCGTGGATGGTCTTCTGGAC & This study \\
\hline AD3rev & GTTGGATCCTCAGCCGGTGATGTCGATGGT & This study \\
\hline AD4for & TGCCCATGGCCGCCAATGCCATGATTCTC & This study \\
\hline AD4rev & TTGGGATCCTCAGTGGGTGCTGAGGGTGTCGTA & This study \\
\hline
\end{tabular}

${ }^{*}$ The locations of the restriction sites used to facilitate cloning of amplified fragments are indicated in bold. 
system (Roche) using primer pair PD1793for and PD1791rev with the following PCR parameters: $2 \mathrm{~min}$ initial denaturation at $94{ }^{\circ} \mathrm{C}$ followed by 10 cycles of denaturing at $94{ }^{\circ} \mathrm{C}$ for $10 \mathrm{~s}$, annealing at $58{ }^{\circ} \mathrm{C}$ for $30 \mathrm{~s}$ and elongation at $68{ }^{\circ} \mathrm{C}$ for $15 \mathrm{~min}$. This was followed by 25 cycles of $94{ }^{\circ} \mathrm{C}$ for $15 \mathrm{~s}$, annealing at $58{ }^{\circ} \mathrm{C}$ for $30 \mathrm{~s}$, and extension at $68{ }^{\circ} \mathrm{C}$ for $15 \mathrm{~min}$ with an increase of $20 \mathrm{~s}$ at $68{ }^{\circ} \mathrm{C}$ with each cycle. The final cycle was $68{ }^{\circ} \mathrm{C}$ for $7 \mathrm{~min}$. The PCR product was cloned into pCR-XL-TOPO (Invitrogen) according to the manufacturer's instructions. The resulting plasmid pCR-PD1792 was used for PCR amplification of adhesion domain 1-3 (AD1-3) and adhesion domain 4 (AD4) (Fig. 1b). AD1-3 was PCR amplified using AD1for and AD3rev; the PCR product was cut with $B s p H I$ and BamHI, and cloned into $\mathrm{pET} 30 \mathrm{~b}(+)$ (Novagen), producing plasmid pET-AD1-3. AD4 was PCR amplified using primer AD4for and AD4rev, cut with $\mathrm{NcoI}$ and BamHI, and the fragment cloned into pET30b $(+)$, producing plasmid pET-AD4. The adhesion domains were expressed as His-fusion proteins using Escherichia coli ArcticExpress (DE3) (Stratagene) according to the manufacturer's instructions and purified by nickel-affinity column chromatography (Qiagen).

The fusion proteins were separated by $12 \%$ SDS-PAGE and the corresponding bands excised, freeze-dried and resuspended in $1 \mathrm{ml}$ $1 \times \mathrm{PBS} /$ Freund's complete adjuvant (Sigma-Aldrich) 50/50 for the first injection and in $1 \mathrm{ml} 1 \times \mathrm{PBS} /$ Freund's incomplete adjuvant (Sigma-Aldrich) 50/50 for three booster injections. Immunizations were conducted by the Comparative Pathology Laboratory at UC Davis. Four hundred micrograms of each fusion protein was injected subcutaneously and $600 \mu \mathrm{g}$ was injected intramuscularly into New Zealand White rabbits on a 10 day schedule. Test bleeds were taken after the third and fourth injections and the rabbits were terminally bled 2 weeks after the fourth injection; serum was stored at $-20{ }^{\circ} \mathrm{C}$

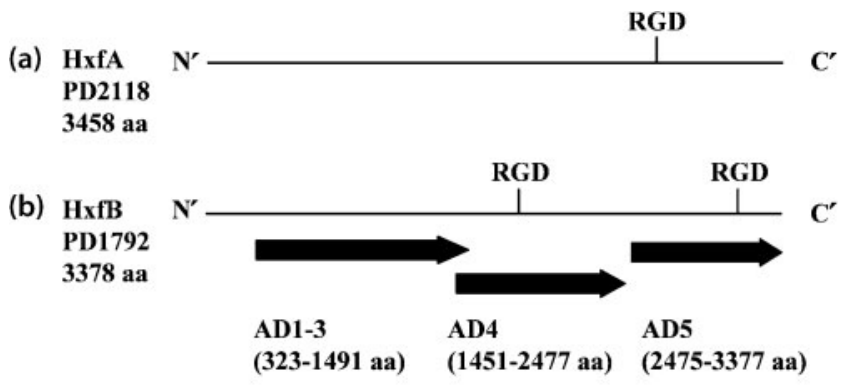

(c)

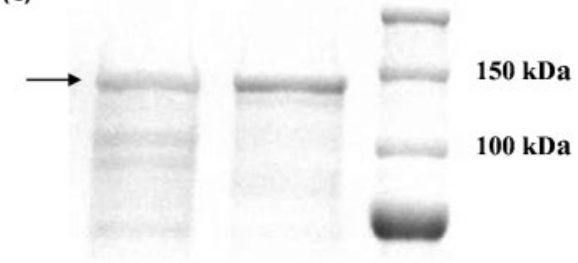

AD1-3 AD4

Fig. 1. $(a, b)$ Schematic showing the location of RGD cell attachment motifs in HxfA (a) and the location of RGD cell attachment motifs relative to the cloned $A D 1-3$ and $A D 4$ fragments in $\mathrm{HxfB}$ (b). (c) Coomassie-blue-stained 3-12\% Tris/ $\mathrm{HCl}$ gradient polyacrylamide SDS-PAGE gel of recombinant AD1-3 and AD4 proteins following purification on nickel-affinity columns. The arrow indicates recombinant proteins that were used as antigens to produce polyclonal antisera. Lane 1, E. coli transformed with pETAD1-3; lane 2, E. coli transformed with pET-AD4; lane 3, molecular mass standards. until used. Indirect ELISA using recombinant fusion proteins was performed to determine the bleed with the highest titre and the optimal working dilution of the antibodies.

Isolation of secreted proteins and vesicles. For identification and purification of secreted HA proteins, supernatants from wild-type Temecula and the HxfA and HxfB mutants were obtained by centrifugation at $3000 \mathrm{~g}$ for $10 \mathrm{~min}$. Twenty millilitres of each supernatant was placed into dialysis tubing (12-14000 MWCO, Spectrum) and dialysed against $1 \times$ PBS, $0.1 \mathrm{M}$ EDTA $(\mathrm{pH} 8.0)$. The samples were concentrated by placing the dialysis tubing onto polyethyleneglycol bisphenol A epichlorohydrin copolymer 15-20 $\mathrm{kDa}$ (Sigma-Aldrich) until a final volume of $5 \mathrm{ml}$ was obtained. Proteins were then isolated using a modified version of a protocol described by Welsch et al. (2007). Briefly, sucrose was added to $5 \mathrm{ml}$ supernatant to a final concentration of $40 \%(\mathrm{w} / \mathrm{v})$. Then, $50 \mu 110 \%$ SDS, $100 \mu \mathrm{l} \beta$-mercaptoethanol and $2 \mathrm{ml}$ phenol were added and the samples vortexed. After centrifugation at $800 \mathrm{~g}$ for $5 \mathrm{~min}$ at room temperature, approximately $2 \mathrm{ml}$ of the top layer was transferred into a new tube and the centrifugation step repeated. To collect the protein fraction, the supernatant was divided into two tubes, Ten millilitres of methanol was added to each tube; the samples were vortexed, and finally centrifuged at $3300 \mathrm{~g}$ for $5 \mathrm{~min}$ at $4{ }^{\circ} \mathrm{C}$. The supernatant was discarded, $10 \mathrm{ml}$ methanol was added to the pellet and the centrifugation step repeated. The resulting pellet was air-dried and resuspended in $100 \mu \mathrm{l} 1 \% \mathrm{SDS} / 65 \mathrm{mM}$ Tris/ $\mathrm{HCl}, \mathrm{pH} 7$.

For isolation of membrane vesicles, wild-type Temecula PD3 supernatant was obtained by centrifugation at $3000 \mathrm{~g}$ for $10 \mathrm{~min}$ and filtered through a $0.45 \mu \mathrm{m}$ sterile filter (Millipore) to ensure elimination of whole cells. The filtrate was centrifuged at $38400 \mathrm{~g}$ for $1 \mathrm{~h}$ at $4{ }^{\circ} \mathrm{C}$ to obtain the vesicle pellet and the culture supernatant fraction. The pellet was resuspended in $1 \% \mathrm{SDS} / 65 \mathrm{mM}$ Tris/HCl, $\mathrm{pH}$ 7. Trichloroacetic acid (TCA) to a final concentration of $13 \%$ was added to the supernatant fraction and the precipitated proteins harvested by centrifugation at $15000 \mathrm{~g}$ for $15 \mathrm{~min}$. The resulting pellet was washed with $70 \%$ ethanol, air-dried, and resuspended in $1 \% \mathrm{SDS} / 65 \mathrm{mM}$ Tris/HCl, $\mathrm{pH} 7$.

Isolation of outer-membrane proteins. Outer-membrane proteins were isolated using a modification of a protocol developed by Nikaido (1983). Briefly, one litre volumes of liquid PD3 culture of wild-type Temecula, the HxfA mutant, and the HxfB mutant were centrifuged at $3000 \mathrm{~g}$ for $10 \mathrm{~min}$ and the resulting X. fastidiosa cells were washed with $10 \mathrm{mM}$ HEPES, pH 7.4. The pellet was resuspended in $5 \mathrm{ml}$ HEPES buffer (10 mM HEPES, pH 7.4, containing $0.02 \mathrm{mg}$ DNase $\mathrm{ml}^{-1}, 0.02 \mathrm{mg}$ RNase $\mathrm{ml}^{-1}, 1 \mathrm{mM}$ PMSF and $0.1 \mathrm{M}$ EDTA). Cells were passed three times through a French pressure cell at 900 p.s.i. $(6.2 \mathrm{MPa})$ and the unbroken cells were removed by centrifugation at $3000 \mathrm{~g}$ for $10 \mathrm{~min}$ at $4{ }^{\circ} \mathrm{C}$. The resulting supernatant was centrifuged at $180000 \mathrm{~g}$ for $1 \mathrm{~h}$ at $4{ }^{\circ} \mathrm{C}$. The pellet was resuspended in $2 \mathrm{ml}$ HEPES buffer and centrifuged at $3000 \mathrm{~g}$ for $2 \mathrm{~min}$ to remove insoluble material. The supernatant was applied on top of a sucrose step gradient consisting of $2.5 \mathrm{ml}$ sucrose solutions at different concentrations $(55 \%, 52.5 \%, 50 \%, 47.5 \%$, w/w). The samples were placed in a swinging-bucket rotor (Beckman SW-41) and centrifuged at $100000 \mathrm{~g}$ for $18 \mathrm{~h}$ at $4{ }^{\circ} \mathrm{C}$. The resulting bands were collected, diluted with $20 \mathrm{ml}$ HEPES buffer and centrifuged at $180000 \mathrm{~g}$ for $1 \mathrm{~h}$. The pellets were resuspended in $100 \mu$ HEPES buffer and stored in $5 \mu \mathrm{l}$ aliquots at $-20{ }^{\circ} \mathrm{C}$. To identify the fraction in the sucrose gradient that contained the outer-membrane proteins, the fractions were subjected to Western blot analysis using anti-MopB polyclonal antibodies (kindly provided by George Bruening, UC Davis).

Western blot analyses. The concentration of protein in the culture supernatant, membrane vesicles and outer-membrane samples was measured using the Bio-Rad Protein Assay according to the 
manufacturer's instructions, and equal amounts of protein were separated by SDS-PAGE on a $3-12 \%$ Tris/ $\mathrm{HCl}$ gradient polyacrylamide gel. The proteins were transferred to a PVDF membrane (Whatman) at $100 \mathrm{~V}$ for $1.5 \mathrm{~h}$ in Towbin buffer (Towbin et al., 1979). After blocking overnight in $1 \%$ nonfat milk in $1 \times \mathrm{PBS}$, the membrane was probed with a $1: 400$ dilution of anti-AD4 antisera or pre-immune serum in $1 \times \mathrm{PBS}$ for $1 \mathrm{~h}$ at $37{ }^{\circ} \mathrm{C}$. After washing three times for 15 min with $1 \times$ PBS, $0.05 \%$ Tween 20 , the membrane was incubated with a $1: 1600$ dilution of goat anti-rabbit alkaline phosphatase conjugate (Bio-Rad) for $1 \mathrm{~h}$ at $37^{\circ} \mathrm{C}$. The membrane was washed four times with $1 \times$ PBS, $0.05 \%$ Tween 20 and bound conjugate was detected using an alkaline phosphatase conjugate substrate kit (Bio-Rad).

Size-exclusion chromatography. Proteins from $10 \mathrm{l}$ of cell-free supernatant from a wild-type Temecula liquid culture were precipitated overnight at $4{ }^{\circ} \mathrm{C}$ by adding solid ammonium sulfate to a final concentration of $70 \%$. The solution was centrifuged at $28000 \mathrm{~g}$ for $20 \mathrm{~min}$ at $4{ }^{\circ} \mathrm{C}$ and the resulting pellet was suspended in $1 \times$ PBS (3-4 ml $1 \times$ PBS for each litre of $X$. fastidiosa culture). The solution was dialysed against $1 \times$ PBS, applied to a Sephacryl S-200 HR column $(2.8 \times 33 \mathrm{~cm}, 203 \mathrm{ml}$ total volume, GE Healthcare $)$ and chromatographed using $0.05 \mathrm{M}$ sodium acetate with $1 \mathrm{M} \mathrm{NaCl}$ at pH 5.0 as the eluant. The column was run at $0.75 \mathrm{ml} \mathrm{min}^{-1}$ with pressure being supplied by a Gilson Miniplus II peristaltic pump (Gilson Medical Electronics). Eighty $3.5 \mathrm{ml}$ fractions were collected using a Gilson FC-80K fraction collector and the fractions containing HAs were identified by Western blot analysis. The fractions containing HAs were pooled, placed into dialysis tubing, and further concentrated by placing the tubes onto polyethyleneglycol bisphenol A epichlorohydrin copolymer $15-20 \mathrm{kDa}$ (Sigma-Aldrich) until a final volume of $2 \mathrm{ml}$ was reached. The sample was dialysed against $1 \times$ PBS and used for mass spectrometry analysis.

Protein identification by mass spectrometry. The proteins obtained by size-exclusion chromatography were separated by SDSPAGE on a $3-12 \%$ Tris/ $\mathrm{HCl}$ gradient polyacrylamide gel and the gel was stained using SYPRO Ruby stain (Sigma-Aldrich). A protein band corresponding to a putative $220 \mathrm{kDa}$ HA protein was excised with a sterile razor blade and analysed by the Genome Center Proteomics Core at the University of California, Davis, using LC MS/MS mass spectrometry. The MS/MS samples were analysed using Mascot (Matrix Science; version 2.1.03) and X! Tandem (http://www.thegpm. org; version 2006.04.01.2).

\section{RESULTS}

\section{In silico analysis of HA proteins}

$X$. fastidiosa Temecula has two homologous HA proteins that exhibit $64.65 \%$ amino acid identity: HxfA $(360 \mathrm{kDa})$ and $\mathrm{HxfB}(355 \mathrm{kDa})$. Analysis of HxfA and HxfB using PROSITE search (http://www.expasy.ch/prosite/) revealed the presence of RGD cell attachment motifs (Arg-Gly-Asp) (Relman et al., 1990) in both HA proteins. The tripeptide RGD has been found in numerous proteins, where it mediates cell adhesion through binding to integrin receptors (D'Souza et al., 1991a, b). In HxfA, one RGD motif was identified at amino acids 2681-2683 (Fig. 1a), and in $\mathrm{HxfB}$, two RGD motifs were identified, at positions 1805-1807 and 3103-3105 (Fig. 1b).

Because HAs are encoded by genes greater than $10 \mathrm{~kb}$ in size, they are difficult to express in E. coli in their native form. To identify smaller regions of the genes that could be expressed for the generation of antibodies, we divided the $h x f A$ and $h \times f B$ genes into fragments we named adhesion domain (AD) 1-3, AD4 and AD5 (Fig. 1a, b). SMART analysis (Simple Modular Architecture Research Tool, http://smart.embl.de/) identified a potential haemagglutination activity domain located in the sequence for AD1-3. This domain is located between positions 69-189 in HxfA and positions 87-207 in HxfB. To predict potential antigenic sites, the protein sequences for the individual ADs were also analysed by the Hopp-Woods scale (http://www.vivo.colostate.edu/molkit/ hydropathy/index.html). AD4 of HxfB exhibited the highest hydrophilicity value and is thus likely to be exposed on the surface of the folded protein, where it should elicit the production of antibodies. Furthermore, alignments of the protein sequences for HxfA and $\mathrm{HxfB}$ showed that their $\mathrm{N}$-terminal 2500 amino acids are $85 \%$ identical and therefore both proteins could potentially be recognized by the antibodies derived from HxfB. For the reasons stated above we chose to generate antibodies against AD1-3 and $\mathrm{AD} 4$ derived from HxfB.

\section{Cloning, expression of AD1-3 and AD4 proteins and generation of anti-HA antibodies}

AD1-3 and AD4 of $\mathrm{HxfB}$ were cloned as described to generate plasmids pET-AD1-3 and pET-AD4 (Table 1). After expression and purification, the recombinant AD1-3 and AD4 fusion proteins were analysed by SDS-PAGE, and proteins of the expected $140 \mathrm{kDa}$ size, as well as some small truncated proteins, were observed (Fig. 1c). The protein bands at $140 \mathrm{kDa}$ were excised and the identity of the fusion proteins confirmed by mass spectrometry analysis. AD1-3 and AD4 fusion proteins were freeze-dried and used as antigen as described in Methods. Indirect ELISA using recombinant AD1-3 and AD4 fusion proteins showed that the terminal bleeds had the highest titre and the optimal working dilution was at 1:400 for both antisera. ELISA using pre-immune serum showed there was no reaction with recombinant AD1-3 and AD4.

\section{HA proteins are processed to $220 \mathrm{kDa}$ and secreted as soluble proteins and in vesicles}

The proteins isolated from culture supernatants of $X$. fastidiosa wild-type Temecula and $\mathrm{HxfA}$ and $\mathrm{HxfB}$ mutants were analysed by Western blot analysis. A prominent doublet of proteins at approximately $220 \mathrm{kDa}$ that corresponds to HxfA and HxfB was observed in wild-type supernatant (Fig. 2a, lane 1), and only one prominent protein band was detected in the HxfA and HxfB mutant supernatant samples. As anticipated based on their predicted molecular mass, the larger prominent protein corresponding to $\mathrm{HxfA}$ is missing in the HxfA mutant (Fig. 2a, lane 2) and the slightly smaller protein band corresponding to $\mathrm{HxfB}$ is missing in the $\mathrm{HxfB}$ mutant (Fig. 2a, lane 3). A less prominent additional protein band in the wild-type and mutant preparations could possibly correspond to PD1246, a truncated HA-like protein 
(a)

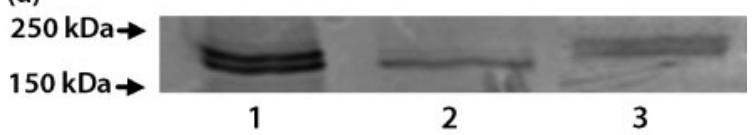

(b)

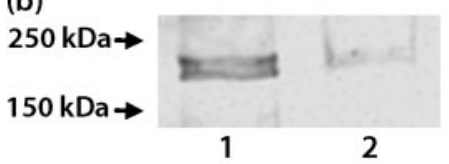

(c)

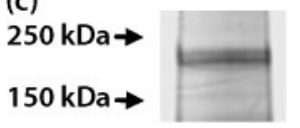

Fig. 2. (a) Western blot analysis of $X$. fastidiosa supernatant developed with anti-AD4 antibodies. Lane 1, wild-type Temecula; lane 2, HxfA mutant; lane 3, HxfB mutant. A doublet of bands in the wild-type Temecula is detectable; the upper band corresponding to $\mathrm{HxfA}$ is missing in the HxfA mutant, and the lower band corresponding to $\mathrm{HxfB}$ is missing in the $\mathrm{HxfB}$ mutant. An additional larger molecular size protein band in the wild-type and mutant preparations possibly corresponds to PD1246, a truncated HAlike $235 \mathrm{kDa}$ protein. (b) Western blot analysis of $X$. fastidiosa vesicle preparation developed with anti-AD4 antibodies. Lane 1, wild-type Temecula vesicle preparations; lane 2, TCA-precipitated supernatant after isolation of vesicles (proteins represent soluble HA proteins). (c) Western blot analysis of outer-membrane protein preparation of wild-type Temecula.

(235 $\mathrm{kDa}$ ) that possesses $44 \%$ amino acid identity with AD4 and therefore could potentially be recognized by the antiAD4 antibodies in the Western blot.

To determine if HA proteins are secreted as soluble proteins or are associated with membrane vesicles, as described for other bacterial pathogens (Kuehn \& Kesty, 2005), the vesicles were collected by centrifugation and proteins remaining in the supernatant were precipitated using TCA. Western blot analysis of the precipitate confirmed the presence of HA proteins as secreted soluble proteins (Fig. 2b, lane 2). Interestingly, $220 \mathrm{kDa}$ proteins in the vesicle fraction were also detected by the anti-AD4 antibody (Fig. 2b, lane 1). Vesicles released from the envelope of growing bacteria can mediate the secretion of virulence factors and are described for many Gram-negative bacteria (Kuehn \& Kesty, 2005). To our knowledge, this is the first report of secretion of an adhesin via membrane vesicles in $X$. fastidiosa.

\section{HA proteins are present in the outer membrane}

Isolated outer-membrane proteins of $X$. fastidiosa wild-type Temecula were analysed by Western blotting. Again, a prominent doublet of bands at $220 \mathrm{kDa}$ corresponding to the mature HA proteins was observed (Fig. 2c). To confirm that an outer membrane was indeed isolated, the Western blot was also developed using anti-MopB antibodies. MopB is the major outer-membrane protein in
$X$. fastidiosa (Bruening et al., 2005), and detection of the 38.5 $\mathrm{kDa}$ band corresponding to MopB confirmed that $X$. fastidiosa HAs, like FHA, are present in the outer membrane (data not shown). The outer-membrane-associated form of B. pertussis FHA was recently proposed to exhibit a different function compared to soluble FHA protein (Abramson et al., 2008).

\section{Examination of the HAs by mass spectrometry}

Although we used 101 of culture supernatant to isolate native HAs, the $220 \mathrm{kDa}$ protein bands in the concentrated sample were barely visible on a Sypro-stained gel that was submitted for mass spectrometry analysis. In spite of this low abundance, we were able to obtain a mass spectrometry result and could analyse the obtained protein sequence by GPM search against the $X$. fastidiosa Temecula database and by Mascot search against the proteobacteria database. The first and the last identified peptides matched the $\mathrm{N}$-terminal amino acid 88 and the $\mathrm{C}$ terminal amino acid 2257 for HxfA and HxfB, respectively. No peptides could be identified downstream of position 2257, indicating that the C-terminal third of the proteins is not present in the mature protein. The calculated molecular mass of the remaining $\mathrm{N}$-terminal part until position 2257 in the processed HA proteins corresponds to the $220 \mathrm{kDa}$ protein that could be observed by Western blot analysis in the secreted protein, vesicle and outermembrane protein fractions. However, the low abundance of secreted HA proteins in X. fastidiosa prevented our Nterminal sequencing effort; therefore we could not identify a signal peptide or cleavage site at the $\mathrm{N}$-terminus.

\section{DISCUSSION}

HA-mediated attachment and biofilm formation in the plant and insect hosts are major virulence mechanisms of $X$. fastidiosa, but nothing was known about the underlying biochemistry of these large proteins or the location of the proteins on the cell. Our research revealed many common features between $X$. fastidiosa HAs and B. pertussis FHA. The similarities between these two adhesins include the processing of a native $360 \mathrm{kDa}$ precursor to a mature 220 $\mathrm{kDa}$ protein, association of the adhesins with the outer membrane as well as secretion into the medium, and the presence of RGD cell attachment motifs. RGD cell attachment motifs in FHA have been suggested to be involved in binding to host cell integrins (Relman et al., 1990). Integrins are receptors that mediate attachment between a cell and the tissues surrounding it, which may be other cells or the extracellular matrix. Integrin-like proteins have also been identified in plants (Faik et al., 1998). When the HA mutant strains were inoculated into grapevine stems, they moved faster than wild-type bacteria (Guilhabert \& Kirkpatrick, 2005). It is possible that faster colonization is due not only to the lack of cell-cell aggregation in the HA mutants, but also to the missing 
RGD motifs in the HA proteins of mutant strains. $X$. fastidiosa cells lacking one of the two HA proteins might adhere less tightly to host factors via a possible RGDintegrin interaction. A recent study (Killiny \& Almeida, 2009) suggests that like FHA, HA proteins also contain a carbohydrate-binding domain that mediates attachment of the bacteria to polysaccharides found in the foregut of the insect vector. Lastly, both organisms use the TPS system for the transport of the adhesins across the outer membrane and have similar N-terminal secretion domains.

Although we observed several structural similarities between HA and FHA, we also found important differences. Besides the $\mathrm{N}$-terminal secretion domain, the adhesins possess very little overall sequence homology to each other. Another major difference is the quantity of the adhesin that is secreted or present on the cell. Our analysis showed that HAs in X. fastidiosa are not very abundant under the conditions we examined, whereas FHA constitutes the major secreted protein in B. pertussis. The different lifestyles of the bacteria might explain this observation, because in contrast to the animal pathogen, $X$. fastidiosa needs to bind effectively to two different hosts, the plant xylem and the foregut of the insect vector (Chatterjee et al., 2008). For effective transmission these attachments need to be reversible to enable uptake of the bacteria from the plant xylem into the insect, and to enable release of the bacteria into the plant xylem during subsequent feeding of the insect. A strong, irreversible attachment to either of the two environments would be limiting to $X$. fastidiosa's life cycle. Other proteins on the surface of $X$. fastidiosa, such as XadA and FimA, might be involved in attachment to host factors as well (Feil et al., 2007).

The detection of the mature $220 \mathrm{kDa}$ HA proteins in all examined fractions - the $X$. fastidiosa supernatant, outermembrane fraction and secreted vesicles - indicates that HA proteins are processed upon secretion and that processing of a pre-protein is necessary for production of biologically functional HAs. Secretion of a large preprotein might be a mechanism to prevent premature folding and aggregation, ensuring a secretion-competent conformation of the proteins that can subsequently be folded at the appropriate time and place. The C-terminal third of the pre-protein might act as a secretion chaperone and is probably cleaved off after secretion and rapidly degraded, because we never detected the whole $360 \mathrm{kDa}$ protein in Western blot analyses. Similar results were observed for FHA, where the protease responsible for the maturation of FHA was identified as SphB1, an autotransporter protein belonging to the subtilisin family (Coutte et al., 2001). In the X. fastidiosa genome, three putative proteases have been identified that exhibit homology to SphB1: PD0313 (28\% identity), PD0218 (28\% identity) and PD0950 (26\% identity) (Van Sluys et al., 2003). One of these $X$. fastidiosa proteases might be responsible for maturation of the HA pre-proteins, and experiments are currently under way to test this hypothesis.
It is possible that these proteases also play a role in the release of adhesins into the extracellular milieu. Proteolytic cleavage of adhesins in vivo might result in release of the bacteria from the initial attachment site. In the insect vector, this mechanism might be necessary for efficient transmission of the bacteria into the plant xylem during feeding. In the plant xylem, cleavage of the adhesins might be important for systemic colonization, as the release may facilitate dispersal of the bacteria from microcolonies to new infection sites. However, we could only show the release of HAs into the bacterial supernatant in vitro; our attempts to detect free HAs in xylem sap of X. fastidiosainoculated grapevines were unsuccessful. We can also speculate that differences in the presentation of HAs (surface-associated versus soluble) may lead to different functions of the adhesin and that the soluble form might have an additional role in pathogenesis, as was shown for FHA (Abramson et al., 2008).

Secretion of virulence factors in vesicles is a novel feature for $X$. fastidiosa pathogenicity that was not previously known for this plant pathogen. Vesiculation is a ubiquitous process for Gram-negative bacteria grown in a variety of environments, including liquid cultures and biofilms (Beveridge, 1999; Kuehn \& Kesty, 2005). Naturally occurring vesicles are typically not products of cell lysis or cell death, but closed outer-membrane 'blebs' produced by growing bacteria (Kuehn \& Kesty, 2005; Mug-Opstelten \& Witholt, 1978; Zhou et al., 1998). In general, pathogenic bacteria produce more vesicles than non-pathogenic bacteria (Lai et al., 1981), and many virulence factors such as toxins (Kolling \& Matthews, 1999; Nowotny et al., 1982; Wensink et al., 1978), proteases (Negrete-Abascal et al., 2000; Rosen et al., 1995) and adhesins (Patrick et al., 1996) are localized in vesicles. Vesicles have also been shown to mediate cell-cell aggregation of bacteria, enabling biofilm formation and colonization (Grenier \& Mayrand, 1987; Whitchurch et al., 2002). The discovery of membrane vesicles in $X$. fastidiosa potentially gives new insights into the disease development of PD. To date, it is not fully understood how symptoms develop in leaves distal from $X$. fastidiosa colonized xylem vessels. It is assumed that the occlusion of the xylem vessels leads to water stress, which causes the leaf symptoms. But the symptoms of a waterstressed grapevine plant without a $X$. fastidiosa infection differ from those of a PD-infected plant (Thorne et al., 2006). Our results provide evidence that $X$. fastidiosa might secrete some of its virulence factors, e.g. toxins, via membrane vesicles that are smaller than the bacteria and may therefore more easily pass through pit membranes and potentially travel long distances in the grapevine xylem. Whether the HA proteins we found in the vesicles play a role in this process and whether the HA proteins are located in the vesicles due to a regulated process, rather than by chance, still needs to be determined.

Our results provide the basis for evaluating a novel form of resistance against $\mathrm{PD}$. By identifying the haemagglutination adhesion domains and the size of the mature HA proteins 
it is feasible to generate HA-expressing grapevine rootstock. We believe that constitutively expressed HA proteins could probably move upward in the xylem by the transpirational stream into the non-transgenic $V$. vinifera fruiting variety. Upon inoculation of $X$. fastidiosa cells through xylem-feeding insects, the HA proteins that are present in the xylem might aid in the agglutination of the introduced cells. Aggregated X. fastidiosa cells should be retarded in their systemic colonization of the grapevine plant and the aggregated bacteria might remain at the point of infection. These sites containing the bacterial aggregates could be pruned off at the end of the grape-growing season, thus preventing overwintering $X$. fastidiosa infections.

\section{ACKNOWLEDGEMENTS}

This research was supported by the California Department of Food and Agriculture Pierce's Disease/Glassy Winged Sharpshooter Research Program. We also like to thank Dr Carl Greve for help with size-exclusion chromatography, Dr George Bruening for supplying the anti-MopB antibodies and Dr Steven Lindow for suggesting that haemagglutinins might be secreted in vesicles.

\section{REFERENCES}

Abramson, T., Kedem, H. \& Relman, D. A. (2008). Modulation of the $\mathrm{NF}-\kappa \mathrm{B}$ pathway by Bordetella pertussis filamentous hemagglutinin. PLoS One 3, e3825.

Beveridge, T. J. (1999). Structures of gram-negative cell walls and their derived membrane vesicles. J Bacteriol 181, 4725-4733.

Bruening, G., Civerolo, E., Lee, Y., Buzayan, J., Feldstein, P. \& Re, E. (2005). A major outer membrane protein of Xylella fastidiosa induces chlorosis in Chenopodium quinoa. Phytopathology 95 (Suppl. 6), S14.

Chatterjee, S., Almeida, R. P. \& Lindow, S. (2008). Living in two worlds: the plant and insect lifestyles of Xylella fastidiosa. Annu Rev Phytopathol 46, 243-271.

Clantin, B., Delattre, A. S., Rucktooa, P., Saint, N., Meli, A. C., Locht, C., Jacob-Dubuisson, F. \& Villeret, V. (2007). Structure of the membrane protein FhaC: a member of the Omp85-TpsB transporter superfamily. Science 317, 957-961.

Coutte, L., Antoine, R., Drobecq, H., Locht, C. \& Jacob-Dubuisson, F. (2001). Subtilisin-like autotransporter serves as maturation protease in a bacterial secretion pathway. EMBO J 20, 5040-5048.

Davis, M. J., French, W. J. \& Schaad, N. W. (1981). Axenic culture of the bacteria associated with phony disease of peach and plum leaf scald. Curr Microbiol 6, 309-314.

de Souza, A. A., Takita, M. A., Coletta-Filho, H. D., Caldana, C., Goldman, G. H., Yanai, G. M., Muto, N. H., de Oliveira, R. C., Nunes, L. R. \& Machado, M. A. (2003). Analysis of gene expression in two growth states of Xylella fastidiosa and its relationship with pathogenicity. Mol Plant Microbe Interact 16, 867-875.

D'Souza, S. E., Ginsberg, M. H., Matsueda, G. R. \& Plow, E. F. (1991a). A discrete sequence in a platelet integrin is involved in ligand recognition. Nature 350, 66-68.

D'Souza, S. E., Ginsberg, M. H. \& Plow, E. F. (1991b). Arginyl-glycylaspartic acid (RGD): a cell adhesion motif. Trends Biochem Sci 16, 246-250.
Faik, A., Laboure, A. M., Gulino, D., Mandaron, P. \& Falconet, D. (1998). A plant surface protein sharing structural properties with animal integrins. Eur J Biochem 253, 552-559.

Feil, H., Feil, W. S. \& Lindow, S. E. (2007). Contribution of fimbrial and afimbrial adhesins of Xylella fastidiosa to attachment to surfaces and virulence to grape. Phytopathology 97, 318-324.

Gottig, N., Garavaglia, B. S., Garofalo, C. G., Orellano, E. G. \& Ottado, J. (2009). A filamentous hemagglutinin-like protein of Xanthomonas axonopodis pv. citri, the phytopathogen responsible for citrus canker, is involved in bacterial virulence. PLoS One 4, e4358.

Grenier, D. \& Mayrand, D. (1987). Functional characterization of extracellular vesicles produced by Bacteroides gingivalis. Infect Immun 55, 111-117.

Guedin, S., Willery, E., Tommassen, J., Fort, E., Drobecq, H., Locht, C. \& Jacob-Dubuisson, F. (2000). Novel topological features of FhaC, the outer membrane transporter involved in the secretion of the Bordetella pertussis filamentous hemagglutinin. J Biol Chem 275, 30202-30210.

Guilhabert, M. R. \& Kirkpatrick, B. C. (2005). Identification of Xylella fastidiosa antivirulence genes: hemagglutinin adhesins contribute to $X$. fastidiosa biofilm maturation and colonization and attenuate virulence. Mol Plant Microbe Interact 18, 856-868.

Guilhabert, M. R., Hoffman, L. M., Mills, D. A. \& Kirkpatrick, B. C. (2001). Transposon mutagenesis of Xylella fastidiosa by electroporation of Tn5 synaptic complexes. Mol Plant Microbe Interact 14, 701706.

Hewitt, W. B., Houston, B. R., Frazier, N. W. \& Freitag, J. H. (1946). Leafhopper transmission of the virus causing Pierce's disease of grape and dwarf of alfalfa. Phytopathology 36, 117-128.

Hopkins, D. L. (1989). Xylella fastidiosa - xylem-limited bacterial pathogen of plants. Annu Rev Phytopathol 27, 271-290.

Jacob-Dubuisson, F., Locht, C. \& Antoine, R. (2001). Two-partner secretion in Gram-negative bacteria: a thrifty, specific pathway for large virulence proteins. Mol Microbiol 40, 306-313.

Jacob-Dubuisson, F., Fernandez, R. \& Coutte, L. (2004). Protein secretion through autotransporter and two-partner pathways. Biochim Biophys Acta 1694, 235-257.

Killiny, N. \& Almeida, R. P. (2009). Xylella fastidiosa afimbrial adhesins mediate cell transmission to plants by leafhopper vectors. Appl Environ Microbiol 75, 521-528.

Kim, S., Malinverni, J. C., Sliz, P., Silhavy, T. J., Harrison, S. C. \& Kahne, D. (2007). Structure and function of an essential component of the outer membrane protein assembly machine. Science 317, 961964.

Kolling, G. L. \& Matthews, K. R. (1999). Export of virulence genes and Shiga toxin by membrane vesicles of Escherichia coli O157: H7. Appl Environ Microbiol 65, 1843-1848.

Kuehn, M. J. \& Kesty, N. C. (2005). Bacterial outer membrane vesicles and the host-pathogen interaction. Genes Dev 19, 2645-2655.

Lai, C. H., Listgarten, M. A. \& Hammond, B. F. (1981). Comparative ultrastructure of leukotoxic and non-leukotoxic strains of Actinobacillus actinomycetemcomitans. J Periodontal Res 16, 379389.

Li, Y., Hao, G., Galvani, C. D., Meng, Y., De La Fuente, L., Hoch, H. C. \& Burr, T. J. (2007). Type I and type IV pili of Xylella fastidiosa affect twitching motility, biofilm formation and cell-cell aggregation. Microbiology 153, 719-726.

Lin, H. (2009). Xylella fastidiosa extracellular genomic DNA enhances biofilm formation in vitro. In Proceedings, 2009 Pierce's Disease Research Symposium California Department of Food and Agriculture, Sacramento, CA, pp. 102-105. 
Liu, D. F., Phillips, E., Wizemann, T. M., Siegel, M. M., Tabei, K., Cowell, J. L. \& Tuomanen, E. (1997). Characterization of a recombinant fragment that contains a carbohydrate recognition domain of the filamentous hemagglutinin. Infect Immun 65, 34653468 .

Locht, C. (2007). Bordetella Molecular Biology. Norwich, UK: Horizon Bioscience.

Meng, Y., Li, Y., Galvani, C. D., Hao, G., Turner, J. N., Burr, T. J. \& Hoch, H. C. (2005). Upstream migration of Xylella fastidiosa via pilusdriven twitching motility. J Bacteriol 187, 5560-5567.

Menozzi, F. D., Boucher, P. E., Riveau, G., Gantiez, C. \& Locht, C. (1994a). Surface-associated filamentous hemagglutinin induces autoagglutination of Bordetella pertussis. Infect Immun 62, 4261-4269.

Menozzi, F. D., Mutombo, R., Renauld, G., Gantiez, C., Hannah, J. H., Leininger, E., Brennan, M. J. \& Locht, C. (1994b). Heparin-inhibitable lectin activity of the filamentous hemagglutinin adhesin of Bordetella pertussis. Infect Immun 62, 769-778.

Mug-Opstelten, D. \& Witholt, B. (1978). Preferential release of new outer membrane fragments by exponentially growing Escherichia coli. Biochim Biophys Acta 508, 287-295.

Negrete-Abascal, E., Garcia, R. M., Reyes, M. E., Godinez, D. \& de la Garza, M. (2000). Membrane vesicles released by Actinobacillus pleuropneumoniae contain proteases and Apx toxins. FEMS Microbiol Lett 191, 109-113.

Nikaido, H. (1983). Proteins forming large channels from bacterial and mitochondrial outer membranes: porins and phage lambda receptor protein. Methods Enzymol 97, 85-100.

Nowotny, A., Behling, U. H., Hammond, B., Lai, C. H., Listgarten, M., Pham, P. H. \& Sanavi, F. (1982). Release of toxic microvesicles by Actinobacillus actinomycetemcomitans. Infect Immun 37, 151-154.

O'Toole, G. A., Pratt, L. A., Watnick, P. I., Newman, D. K., Weaver, V. B. \& Kolter, R. (1999). Genetic approaches to study of biofilms. Methods Enzymol 310, 91-109.

Patrick, S., McKenna, J. P., O’Hagan, S. \& Dermott, E. (1996). A comparison of the haemagglutinating and enzymic activities of Bacteroides fragilis whole cells and outer membrane vesicles. Microb Pathog 20, 191-202.

Relman, D., Tuomanen, E., Falkow, S., Golenbock, D. T., Saukkonen, K. \& Wright, S. D. (1990). Recognition of a bacterial adhesion by an integrin: macrophage CR3 (alpha M beta 2, CD11b/CD18) binds filamentous hemagglutinin of Bordetella pertussis. Cell 61, 1375-1382.

Renauld-Mongenie, G., Cornette, J., Mielcarek, N., Menozzi, F. D. \& Locht, C. (1996). Distinct roles of the N-terminal and C-terminal precursor domains in the biogenesis of the Bordetella pertussis filamentous hemagglutinin. J Bacteriol 178, 1053-1060.

Rodrigues, C. M., Takita, M. A., Coletta-Filho, H. D., Olivato, J. C., Caserta, R., Machado, M. A. \& de Souza, A. A. (2008). Copper resistance of biofilm cells of the plant pathogen Xylella fastidiosa. Appl Microbiol Biotechnol 77, 1145-1157.
Rojas, C. M., Ham, J. H., Deng, W. L., Doyle, J. J. \& Collmer, A. (2002). HecA, a member of a class of adhesins produced by diverse pathogenic bacteria, contributes to the attachment, aggregation, epidermal cell killing, and virulence phenotypes of Erwinia chrysanthemi EC16 on Nicotiana clevelandii seedlings. Proc Natl Acad Sci U S A 99, 13142-13147.

Roper, M. C., Greve, L. C., Labavitch, J. M. \& Kirkpatrick, B. C. (2007). Detection and visualization of an exopolysaccharide produced by Xylella fastidiosa in vitro and in planta. Appl Environ Microbiol 73, 7252-7258.

Rosen, G., Naor, R., Rahamim, E., Yishai, R. \& Sela, M. N. (1995). Proteases of Treponema denticola outer sheath and extracellular vesicles. Infect Immun 63, 3973-3979.

Rossetti, M., Garnier, M., Bove, J. M., Beretta, M. J. G., Teixeira, A. R. R., Quaggio, J. A. \& de Negri, J. D. (1990). Présence de bactéries dans le xylème d'orangers atteints de chlorose variégée, une nouvelle maladie des agrumes au Brésil. C R Acad Sci III, Sci Vie 310, 345-349.

Simpson, A. J. G., Reinach, F. C., Arruda, P., Abreu, F. A., Acencio, M., Alvarenga, R., Alves, L. M., Araya, J. E., Baia, G. S. \& other authors (2000). The genome sequence of the plant pathogen Xylella fastidiosa. Nature 406, 151-157.

Thorne, E. T., Stevenson, J. F., Rost, T. L., Labavitch, J. M. \& Matthews, M. A. (2006). Pierce's disease symptoms: comparison with symptoms of water deficit and the impact of water deficits. Am J Enol Vitic 57, 1-11.

Towbin, H., Staehelin, T. \& Gordon, J. (1979). Electrophoretic transfer of proteins from polyacrylamide gels to nitrocellulose sheets: procedure and some applications. Proc Natl Acad Sci U S A 76, 4350-4354.

Van Sluys, M. A., de Oliveira, M. C., Monteiro-Vitorello, C. B., Miyaki, C. Y., Furlan, L. R., Camargo, L. E., da Silva, A. C., Moon, D. H., Takita, M. A. \& other authors (2003). Comparative analyses of the complete genome sequences of Pierce's disease and citrus variegated chlorosis strains of Xylella fastidiosa. J Bacteriol 185, 1018-1026.

Welsch, R., Maass, D., Voegel, T., Dellapenna, D. \& Beyer, P. (2007). Transcription factor RAP2.2 and its interacting partner SINAT2: stable elements in the carotenogenesis of Arabidopsis leaves. Plant Physiol 145, 1073-1085.

Wensink, J., Gankema, H., Jansen, W. H., Guinee, P. A. \& Witholt, B. (1978). Isolation of the membranes of an enterotoxigenic strain of Escherichia coli and distribution of enterotoxin activity in different subcellular fractions. Biochim Biophys Acta 514, 128-136.

Whitchurch, C. B., Tolker-Nielsen, T., Ragas, P. C. \& Mattick, J. S. (2002). Extracellular DNA required for bacterial biofilm formation. Science 295, 1487.

Zhou, L., Srisatjaluk, R., Justus, D. E. \& Doyle, R. J. (1998). On the origin of membrane vesicles in gram-negative bacteria. FEMS Microbiol Lett 163, 223-228.

Edited by: C. A. Boucher 